\title{
Investigation on the Effects of Hydroponic-planting Versus Soil-planting Using Plectranthus amboinicus as a Plant Model
}

\author{
Shaila Mohana Dass ${ }^{1}$, Tsun-Thai Chai ${ }^{2}$, Fai-Chu Wong *2 \\ ${ }^{1}$ Biochemistry Program, Department of Chemical Science, Faculty of Science, Universiti Tunku Abdul Rahman, \\ 31900 Kampar, Malaysia \\ ${ }^{2}$ Centre for Agriculture and Food Research, Universiti Tunku Abdul Rahman, Jalan Universiti, Bandar Barat, \\ 31900 Kampar, Malaysia
}

\section{Article history:}

Submission July 2021

Revised July 2021

Accepted September 2021

*Corresponding author:

E-mail: wongfc@utar.edu.my

\begin{abstract}
Hydroponic system is a method of growing crops or plants in a soilless system, by suspending the plant crops in a nutrient-rich solution, with reduced interferences from factors such as soil quality, irrigation and climate. However, there is limited information available on how hydroponic planting will affect the plant's bioactivities, as well as the associated biochemical, mineral, phytochemical and antioxidant enzyme contents. In this study, we used Plectranthus amboinicus (Indian borage) as a medicinal plant model, to investigate the differences between hydroponic-planted (HP) versus soil-planted (SP) plants. Here, aqueous extracts of Indian borage from HP and SP samples were prepared, followed by testing for their phytochemical, mineral, chlorophyll and carotenoid contents. Based on our results, SP sample was detected with higher antioxidant potentials, using two different radical scavenging assays. This observation is correlating to the higher phytochemical contents (total phenolic, flavonoid, and hydroxycinnamic acids contents), as well as higher chlorophyll and carotenoid contents, detected in the SP sample. However, no significant difference was detected between HP and SP samples, in terms of their protein protection potentials. On the other hand, HP sample was tested with higher mineral contents (iron, copper, magnesium and calcium) using the atomic absorption spectroscopy method. Additionally, higher antioxidative enzymes (superoxide dismutase, catalase) were also detected in the HP sample using in vitro biochemical assays. In the future study, more plant models can be included in the comparison between HP and SP effects, to determine if a similar phenomenon is observed. Through similar studies, more related information could be gathered to guide the choice of suitable planting systems with regard to food security, in terms of both harvest yields and nutritional contents.
\end{abstract}

Keywords: Antioxidant enzymes, Biochemical phytochemicals, Food security, Hydroponics, Nutritional contents

\section{Introduction}

Medicinal plants represent a vast reservoir of natural bioactive compounds widely appreciated and utilized in traditional medicines [1]. A certain number of modern medicinal drugs are produced using natural products, for instance, medicinal plant-derived chemotherapeutic analogs such as vinblastine and topotecan [2, 3]. Among the large group of medicinal plants studied and reported to date, Plectranthus amboinicus represents an interesting and potentially rewarding medicinal herb worth further investigation. $P$. amboinicus, known as Indian borage or Mexico mint, is a member of the Lamiaceae family and grows naturally in tropical and subtropical areas. In folk medicine, the decoction of Indian borage leaves was used to treat cough and skin irritation [4]. Indian borage has also been reported with various pharmacological and bioactive potentials such as diuretic, antioxidative and antimicrobial properties $[1,5]$. Additionally, Indian borage's analgesic, anti- 
inflammatory, diuretic and anti-hyperglycemic potentials tested using animal models have also been reported by different research groups [6-8].

Hydroponic system is a method of growing crops or plants in a soilless system, by suspending the plant crops in a nutrient-rich solution, with reduced interferences from factors as soil quality, irrigation and climate [9]. Using hydroponic systems, a variety of vegetables and fruits could be produced. Compared to traditional soil planting, hydroponic planting has many positive aspects including better control of plant growing environment and nutrients, as well as better utilization of land space. Additionally, irrigation water wastage can be reduced in hydroponic system, in addition to healthier plants, as exposure to pests and soilborne diseases are minimized [10-12]. Previously, there were studies reported on how soil-planted and hydroponic-planted affected the crops' biochemical contents. For instance, using okra (Abelmoschus esculentus), as a plant model, one study reported on the observation of higher chlorophyll contents in crops harvested from the soilless culture [13]. Another study reported on higher mineral contents in hydroponic-planted strawberries, compared to those grown in soil systems [14]. A separate study compared how hydroponic and soil planting would affect the quality and shelf life of lettuce (Lactuca sativa L.) [15].

However, there is limited information available on how hydroponic planting will affect the medicinal plants' bioactivities, as well as their associated biochemical, mineral, phytochemical and antioxidant enzyme contents. Importantly, these factors are frequently linked with the health-promoting potentials of medicinal plants. In this study, we used Indian borage as a plant model, to investigate the differences between hydroponicplanted (HP) versus soil-planted (SP) medicinal plant. Indian borage was selected as it had been reported with numerous medicinal properties as mentioned above. Here, aqueous extracts of Indian borage from HP and SP samples were prepared, followed by testing for their phytochemical, mineral, chlorophyll and carotenoid contents. In addition, we also tested the HP and SP Indian borage extracts for their anti-oxidative and protein protection potentials. Concurrently, we also quantified the herb's antioxidative enzyme contents, focusing on catalase and superoxide dismutase. Through this study, we hope to provide some useful information on how HP and SP could potentially affect the harvested medicinal herbs, using Indian borage as a plant model.

\section{Material and Methods \\ Herb extract preparation}

Indian borage shoots from ten plants of similar age of 2 weeks were planted side by side in a shady area, using soil planting or hydroponic planting of five plants each in Perak, Malaysia. For hydroponic planting, the Kratky method was used where mesh pots holding plants were placed in a container containing nutrient solution while suspending the roots into the solution. Commercial hydroponic grow medium solution (Well Grow Seeds Co.) was prepared by diluting $5 \mathrm{~mL}$ of Hydroponic Solution A (Ca, $\mathrm{NO}_{3}, \mathrm{NH}_{4}, \mathrm{Fe}, \mathrm{K}$ ) and Solution B $\left(\mathrm{H}_{2} \mathrm{PO}_{4}, \mathrm{SO}_{4}, \mathrm{~K}, \mathrm{Mg}, \mathrm{B}, \mathrm{Cu}, \mathrm{Mo}\right)$ with $2 \mathrm{~L}$ of tap water. After two months, the leaves of similar sizes were harvested from four plants of each planting, washed using distilled water and oven-dried at $60{ }^{\circ} \mathrm{C}$ for 3 days. The dried leaves were ground into a fine powder, and the 1:19 water mixture was heated at $90{ }^{\circ} \mathrm{C}$ for 1 hour. Next, the mixture was filtered using a cheesecloth before the supernatant was centrifuged at 10,000 rpm for 10 min. After centrifugation, supernatants were stored at $-20{ }^{\circ} \mathrm{C}$. For the determination of antioxidant enzyme contents, fresh leaf samples without heating were used.

\section{Determination of radical scavenging potentials}

Free radical scavenging potentials of the plant extract were determined as previously described using two different assays, namely 2, 2'azino-bis (3-ethylbenzthiazoline-6- sulphonic acid) (ABTS) and 2,2-diphenyl-1-picrylhydrazyl $(\mathrm{DPPH})$ assay $[3,16]$. To determine the radical scavenging potential, $10-20 \mu \mathrm{L}$ of the plant extract was added to $200 \mu \mathrm{L}$ of ABTS or DPPH working solution, with absorbance recorded at $734 \mathrm{~nm}$ and $517 \mathrm{~nm}$, respectively, using a microplate reader (FLUO star Omega, BMG Labtech). Radical scavenging activities (\%) were then calculated as shown below and reported as $\mathrm{EC}_{50}$ values (concentrations required to scavenge $50 \%$ of the free radicals):

$$
\begin{aligned}
& \text { Radical scavenging ability (\%) } \\
& =\left(\mathrm{A}_{\text {control }}-\mathrm{A}_{\text {sample }}\right) / \mathrm{A}_{\text {control }} \times 100 \%
\end{aligned}
$$

\section{Determination of phytochemical contents}

Phytochemical contents were determined using previously published conditions. Briefly, 
Total phenolic content (TPC) was determined using Folin-Ciocalteu reagent, with absorbance recorded at $765 \mathrm{~nm}$. TPC was reported as $\mathrm{mg}$ gallic acid equivalents/g dry matter (mg GAE/g DM). Total flavonoid content (TPC) was determined using aluminium chloride reagent, with absorbance recorded at $510 \mathrm{~nm}$, and TFC reported as mg quercetin equivalents /g dry matter (mg QE/g DM). Total hydroxycinnamic acid content (THC) was determined using Arnow's reagent, and THC was reported as mg caffeic acid equivalents/g dry matter (mg CAE/g DM) $[3,16]$.

\section{Determination of antioxidant enzyme contents}

The activity of superoxide dismutase (SOD) was determined by measuring the inhibition of nitroblue tetrazolium (NBT) reduction [17-18]. Briefly, a $3 \mathrm{~mL}$ reaction mixture containing 100 mM potassium phosphate buffer (pH 7.8), $0.1 \mathrm{mM}$ EDTA, $13 \mathrm{mM}$ methionine, $2.25 \mathrm{mM}$ NBT (Sigma-Aldrich), $60 \mu \mathrm{M}$ riboflavin (SigmaAldrich), and leaf extract sample (25-100 $\mu \mathrm{L}$ of 50 $\mathrm{mg} / \mathrm{mL}$ ) was prepared. The reaction mixture was then incubated under fluorescent light for $15 \mathrm{~min}$ and the absorbance was read at $560 \mathrm{~nm}$. In control, the leaf extract sample was substituted with distilled water. The inhibition of NBT reduction was calculated as shown below:

$$
\begin{aligned}
& \text { Inhibition of NBT reduction (\%) } \\
& =\left(A_{\text {control }}-A_{\text {sample }}\right) / A_{\text {control }} \times 100 \%
\end{aligned}
$$

One unit of SOD activity is defined as the enzyme amount needed for $50 \%$ inhibition. The result was expressed as Unit/mg protein. On the other hand, the catalase activity of Indian borage leaf extract was determined as previously reported, with some modifications [17, 19]. Here, a $3 \mathrm{~mL}$ reaction mixture containing $50 \mathrm{mM}$ potassium phosphate buffer (pH 7.0), $0.25 \mathrm{~mL}$ leaf extract sample and $60 \mathrm{mM}$ hydrogen peroxide $\left(\mathrm{H}_{2} \mathrm{O}_{2}\right)$ was prepared. Next, the decrease in absorbance at $240 \mathrm{~nm}$ was measured for $3 \mathrm{~min}$. The $\mathrm{H}_{2} \mathrm{O}_{2}$ decomposition was calculated based on the extinction coefficient, $43.6 \mathrm{M}^{-1} \mathrm{~cm}^{-1}$. One unit of catalase activity is defined as enzyme amount to decompose one $\mu \mathrm{mol}$ of hydrogen peroxide per minute per $\mathrm{mg}$ of protein. The result was expressed as unit/mg protein.

\section{Albumin protein denaturation inhibitory assay Protein protection potential was determined}

using an albumin denaturation inhibitory assay [20-22]. Briefly, a reaction mixture containing 20 $\mathrm{uL}$ of BSA (1 mg/mL), $100 \mathrm{uL}$ of leaf extract and $140 \mathrm{uL}$ of phosphate buffered saline $(50 \mathrm{mM})$ was mixed in a tube and incubated at $80^{\circ} \mathrm{C}$ for $25 \mathrm{~min}$. Then, the $660 \mathrm{~nm}$ absorbance was determined and the percentage of denaturation inhibition was calculated using the following equation:

$$
\begin{aligned}
& \text { Percentage of denaturation inhibition }(\%)= \\
& \left(\mathrm{A}_{\text {control }}-\mathrm{A}_{\text {sample }}\right) / \mathrm{A}_{\text {control }} \times 100 \%
\end{aligned}
$$

\section{Determination of chlorophyll, carotenoids}

Chlorophyll and carotenoid contents were determined according to published conditions [23]. Briefly, $0.5 \mathrm{~g}$ of stripped fresh Indian borage leaf was added into $10 \mathrm{~mL}$ of $98 \%$ acetone in a tube. The tube was then covered and incubated overnight for $4^{\circ} \mathrm{C}$. The absorbance of the sample solution was then measured at three different wavelengths, namely 661.6, 644.8 and $470.0 \mathrm{~nm}$.

\section{Determination of vitamin $C$ content}

Briefly, $1 \mathrm{~mL}$ of leaf extract sample (50 $\mathrm{mg} / \mathrm{mL}$ ) and $9 \mathrm{~mL}$ of $0.5 \%$ oxalic acid were mixed into a conical flask, and placed beneath a burette containing $0.02 \%$ 2, 6-dichlorophenol indophenol (DCPIP) solution. The DCPIP solution was then titrated dropwise into the sample solution in the flask until a faint pink color was observed. This titration process was repeated three times to determine the average volume of DCPIP solution used for each sample, and ascorbic acid standard (HmbG Chemicals) was used as the standardization reference [24]. The results were then determined and expressed as mg of ascorbic acid per gram of leaf sample.

\section{Determination of mineral contents}

Metal content analysis using atomic absorption spectroscopy (AAS) was performed using published conditions with some modifications [25]. Briefly, fresh Indian borage leaves were oven-dried at $60^{\circ} \mathrm{C}$ for 3 days and ground into a fine powder using an electric grinder. Next, $0.1 \mathrm{~g}$ of the powdered plant sample was added into 10 $\mathrm{mL}$ 65\% nitric acid $\left(\mathrm{HNO}_{3}\right)$ and boiled for 15 minutes. Then, the mixture was cooled at room temperature and filtered using filter paper to remove impurities. The filtrate was then topped up to the final volume of $50 \mathrm{~mL}$ with distilled water. The following eight selected metals: aluminium 
Table 1. Hydroponic-planted Indian borage (HPIB) versus soil-planted Indian borage (SPIB) extracts and their $\mathrm{EC}_{50}$ values for radical scavenging and albumin protein protection potentials

\begin{tabular}{cccc}
\hline & \multicolumn{3}{c}{ EC $_{50}$ Values (mg/mL) } \\
\hline & DPPH radical scavenging po- & ABTS radical scaveng- & Albumin protein protec- \\
tential & ing potential & $21.44 \pm 0.21^{\mathrm{a}}$ \\
HPIB & $26.66 \pm 0.18^{\mathrm{a}}$ & $13.39 \pm 0.27^{\mathrm{a}}$ & $21.21 \pm 0.21^{\mathrm{a}}$ \\
\hline SPIB & $2.49 \pm 0.00^{\mathrm{b}}$ & $2.13 \pm 0.01^{\mathrm{b}}$ & 2130 tial \\
\hline
\end{tabular}

Table 2. Hydroponic-planted Indian borage (HPIB) versus soil-planted Indian borage (SPIB) extracts and their phytochemical components

\begin{tabular}{ccccc}
\hline & $\begin{array}{c}\text { TPC } \\
\text { (mg GAE/g DW) }\end{array}$ & $\begin{array}{c}\text { TFC } \\
(\mathrm{mg} \mathrm{QE} / \mathrm{g} \mathrm{DW})\end{array}$ & $\begin{array}{c}\text { THC } \\
(\mathrm{mg} \mathrm{CAE} / \mathrm{g} \mathrm{DW})\end{array}$ & $\begin{array}{c}\text { Vit C } \\
(\mathrm{mg} / \mathrm{g})\end{array}$ \\
\hline HPIB & $7.00 \pm 0.00^{\mathrm{b}}$ & $24.67 \pm 1.76^{\mathrm{b}}$ & $46.33 \pm 0.88^{\mathrm{b}}$ & $0.63 \pm 0.04^{\mathrm{b}}$ \\
SPIB & $20.00 \pm 0.00^{\mathrm{a}}$ & $145.00 \pm 0.00^{\mathrm{a}}$ & $104.67 \pm 0.67^{\mathrm{a}}$ & $0.93 \pm 0.09^{\mathrm{a}}$ \\
\hline
\end{tabular}

Note: Data $(\mathrm{n}=3)$ are reported as mean \pm SE values. The superscripts $(\mathrm{a}-\mathrm{b})$ indicate significant differences $(\mathrm{p}<$ 0.05), for total phenolic content (TPC), total flavonoid content (TFC), total hydroxycinnamic acid content (THC), and ascorbic acid (Vit C).

Table 3. Hydroponic-planted Indian borage (HPIB) versus soil-planted Indian borage (SPIB) extracts and their chlorophyll and carotenoid contents.

\begin{tabular}{cccc}
\hline & $\mathrm{Chl}_{\mathrm{a}}(\mu \mathrm{g} / \mathrm{ml})$ & $\mathrm{Chl}_{\mathrm{b}}(\mu \mathrm{g} / \mathrm{ml})$ & $\mathrm{C}_{\mathrm{x}+\mathrm{c}}(\mu \mathrm{g} / \mathrm{ml})$ \\
\hline HPIB & $0.98 \pm 0.03^{\mathrm{b}}$ & $0.38 \pm 0.02^{\mathrm{b}}$ & $0.49 \pm 0.00^{\mathrm{b}}$ \\
SPIB & $1.28 \pm 0.03^{\mathrm{a}}$ & $0.90 \pm 0.08^{\mathrm{a}}$ & $0.69 \pm 0.01^{\mathrm{a}}$ \\
\hline
\end{tabular}

Note: Data $(\mathrm{n}=3)$ are reported as mean \pm SE values. The superscripts (a-b) indicate significant differences (p $<0.05)$, for chlorophyll a ( Chl a), chlorophyll b ( $\mathrm{Chl} b)$, and carotenoids $\left(\mathrm{C}_{\mathrm{x}+\mathrm{c}}\right)$.

$(\mathrm{Al})$, cadmium $(\mathrm{Cd})$, calcium $(\mathrm{Ca})$, copper $(\mathrm{Cu})$, Iron $(\mathrm{Fe})$, magnesium $(\mathrm{Mg})$, lead $(\mathrm{Pb})$ and zinc (Zn) were analyzed using a flame atomic absorption spectrometer (FAAS) (Agilent Flame Atomic Absorption Spectrometer Model 280FSAA).

\section{Results and Discussions}

In order to assess the influences of different planting systems on the plant's bioactive contents and bioactivity potentials, the leaf extracts were prepared from the soil-planted (SP) and hydroponic-planted (HP) Indian borage. Subsequently, the prepared SP and HP leaf extracts were tested for their various potentials. Concurrently, the leaf extracts were also tested for the phytochemical contents, chlorophyll contents, minerals and antioxidative enzyme contents.

\section{Antioxidant and protein protection potentials}

The SP and HP leaf extracts were first tested for their antioxidant potentials, using two in vitro assays, namely ABTS and DPPH free radical scavenging assays (Table 1 ). Here, the leaf extract samples were tested for their antioxidant potentials, by assessing their abilities to scavenge and neutralize the free radicals. The leaf extract samples were tested in a range of concentrations from 10 to $40 \mathrm{mg} / \mathrm{mL}$, and the results were reported as
$\mathrm{EC}_{50}$ values, with the $\mathrm{EC}_{50}$ defined as the concentration required to scavenge $50 \%$ of the free radicals [22]. Based on Table 1, SP leaf extract demonstrated stronger antioxidant potentials, as represented by the lower $\mathrm{EC}_{50}$ values in both assays. Compared to HP leaf extract, SP leaf extract demonstrated stronger antioxidant potentials that are 10.7 and 6.3 folds, in the DPPH and ABTS radical scavenging assays, respectively. We also tested the HP and SP leaf extract for their protein protection potential, using an in vitro albumin protein protection assay (Table 1). Here, the leaf extract samples were assessed spectrophotometrically for their ability to inhibit the albumin protein denaturation [20-21]. However, we did not detect any significant difference between the protein protection potentials of HP and SP leaf extract samples.

\section{Phytochemical and chlorophyll contents analysis}

The leaf extract for the soil-planted (SP) and hydroponic-planted (HP) Indian borage were next tested for their phytochemical contents (total phenolic, total flavonoid, total hydroxycinnamic acid), as well as ascorbic acid content (Table 2). Based on Table 2, SP Indian borage leaf extract has higher total phenolic content (2.9 folds), total flavonoid content (5.9 folds) and total hydroxy- 


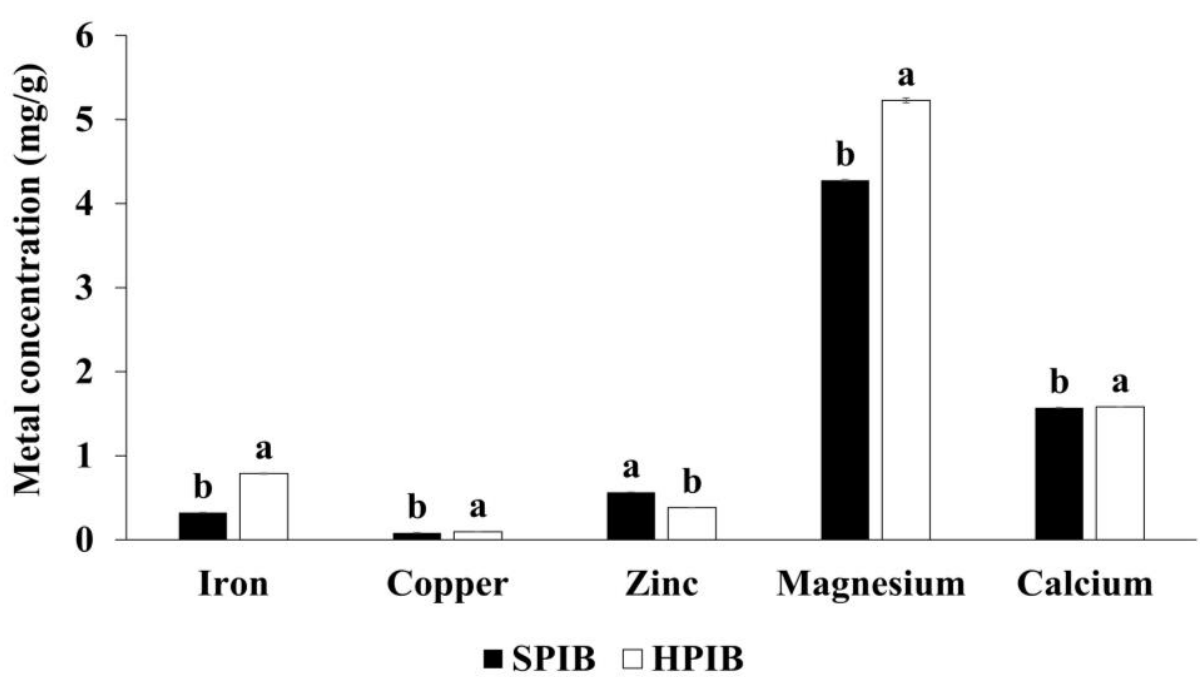

Figure 1. Metal contents in hydroponic-planted Indian borage (HPIB) and soil-planted Indian borage (SPIB) extracts. The superscripts (a-b) indicate statistically significant differences $(\mathrm{p}<0.05)$

cinnamic acid (2.3 folds), compared to HP Indian borage leaf extract. Similarly, SP sample was also tested with higher ascorbic acid content (1.5 folds). Concurrently, SP and HP samples were also tested for their chlorophyll and carotenoid contents (Table 3). Here, SP sample was tested with higher chlorophyll and carotenoid contents (1.3-2.4 folds) compared to HP sample (Table 3).

\section{Plant metal and antioxidant enzyme contents analysis}

Atomic absorption spectroscopy (AAS) was applied to analyse eight selected metal contents in the SP and HP leaf samples (Figure 1). Here, higher iron, copper, magnesium and calcium contents (ranged from 1.01 to 2.44 folds) were detected in HP samples, while higher zinc content (1.47 folds) was detected in SP samples. Zero lead, cadmium and aluminium were detected in both SP and HP samples. Lastly, the SP and HP leaf extract samples were also tested for the antioxidant enzyme contents. Here, we focus on two selected plant antioxidant enzymes, namely superoxide dismutase (SOD) and catalase, as these two enzymes are frequently linked with the plant antioxidant potentials [26-28]. Based on our result, HP Indian borage leaf samples demonstrated a higher SOD (1.5 folds) and catalase (2.1 folds) contents, compared to SP samples (Table 4).

Indian borage was chosen as a plant model, to investigate the differences between hydroponicplanted (HP) versus soil-planted (SP) medicinal plant in terms of their bioactive contents and potentials. Here, we are interested to test if different planting systems would affect the bioactive potentials of medicinal herbs. To achieve these goals, leaf extracts of Indian borage from HP and SP were prepared, followed by testing for their antioxidative and protein protection potentials. Testing on anti-oxidative and protein protection potentials were selected, as these in vitro parameters are widely used to assess medicinal herb health-promoting potentials [29-30]. Previously, excess free radicals have been linked to damages on various cellular components, while cellular proteins degradation has been linked with neurovegetative diseases [20, 31].

In our study, two different radical scavenging assays, namely DPPH and ABTS free radical scavenging assays, were chosen to assess the antioxidative potentials of the HP and SP leaf extracts (Table 1). Previous studies reported how different radical scavenging assays would differ in the detected antioxidant potentials, affecting factors such as media polarity, sample solubility, and different antioxidative mechanisms [32-35]. To avoid the contradiction in results due to different antioxidant assays, we chose to investigate the antioxidant potentials of our HP and SP leaf extracts sample using the aforementioned antioxidant assays. Here, the antioxidant potentials of our HP and SP samples were assessed, based on their abilities to scavenge the DPPH and ABTS free radicals, and the results were reported as $\mathrm{EC}_{50}$ values (Table 1). The $\mathrm{EC}_{50}$ value is defined as the concentration needed to scavenge $50 \%$ of the free radicals, with a smaller EC $_{50}$ value corresponding to a more potent antioxidant capability [22]. 
Consistently, SP Indian borage leaf extract was tested with a smaller $\mathrm{EC}_{50}$ value in both antioxidant assays (Table 1). In addition to antioxidant potentials, we also tested the HP and SP leaf extracts for their protein protection potentials, based on the sample ability to inhibit the albumin protein degradation and the formation of protein aggregates [20,21]. However, we did not detect any significant difference in protein protection potentials, between the HP and SP samples (Table 1).

As previously reported by numerous other studies, the antioxidant potentials of medicinal plants were directly related to their phytochemical contents [29, 36]. In order to determine if there is a similar trend in our study, we also tested the SP and HP leaf extracts for the phytochemical contents (Table 2). Here, the SP and HP samples were tested for their total phenolic, total flavonoid and total hydroxycinnamate, as well as ascorbic acid contents. These bioactive contents were chosen to be investigated, as previous studies interrelate the functional roles of these parameters toward medical plant's antioxidant potentials [37, 38]. Consistently, the SP leave sample exceeded the HP leaf sample in all these bioactive contents tested, in the range of 1.5-5.8 folds (Table 2). Among the bioactive content tested, SP leaves sample demonstrated the highest fold difference (5.8 folds) in total flavonoid contents (TFC), when compared to HP sample. The higher bioactive phytochemical contents as detected in SP samples may help to explain its potent antioxidant capacity, as demonstrated by the lower EC 50 values (Table 1). This observation is consistent with many previously reported cases of direct relationship between medicinal herbs' radical scavenging potentials with various phytochemicals contents [36, 38-39].

Other than phytochemical contents, we also tested the HP and SP Indian borage leaf extracts for their chlorophyll and carotenoid contents, as earlier studies reported on the antioxidant potentials of carotenoids [32, 40]. Based on Table 3, the SP leaf extract possessed higher chlorophyll and carotenoids contents than HP leaf extract. In a previously reported study, okra (Abelmoschus esculentus) and moong (Vigna radiata) plants grown in soilless hydroponic culture were reported with higher chlorophyll content [13]. However, based on our current studies using Indian borage as a plant model, it remains unclear how the chlorophyll and carotenoid contents are interrelated to
Table 4. HPIB (hydroponic) and SPIB (soil) leaf samples, tested for their antioxidant enzymes contents.

\begin{tabular}{ccc}
\hline & SOD (U/mg) & CAT (U/mg) \\
\hline HPIB & $20.84 \pm 0.01^{\mathrm{a}}$ & $19.91 \pm 0.39^{\mathrm{a}}$ \\
SPIB & $13.98 \pm 0.04^{\mathrm{b}}$ & $9.45 \pm 0.27^{\mathrm{b}}$ \\
\hline
\end{tabular}

Note: Superoxide dismutase (SOD) and catalase (CAT) antioxidant enzymes contents, reported as Unit (U) per milligram (mg) of protein.

antioxidant potentials as carotenoid's antioxidant potential has previously been reported to be predominant in the hydrophobic lipid phase [32].

Plant antioxidant enzymes refer to a group of endogenous enzymes which help to neutralize free radicals arising from abiotic and biotic stress, as well as from the normal cellular metabolism processes. Previous studies have highlighted how the plant's antioxidant enzymes could contribute toward antioxidant capability and stress tolerance [27, 41, 42]. Likewise, several studies also highlighted stress factors could affect the antioxidant enzyme contents in hydroponic-grown plants [4345]. However, few studies reported how soil and hydroponic planting methods would affect the plant's antioxidant enzyme contents [46]. In this study, we also quantified the soil-planted (SP) versus hydroponic-planted (HP) herb extracts' antioxidative enzyme contents, focusing on catalase and superoxide dismutase (Table 4). Based on our results, HP leaf extracts possess higher catalase and superoxide dismutase contents (1.5 and 2.1 folds, respectively), compared to its SP counterpart. A possible explanation for this observation may be due to the hydroponic-planting system facilitated the ease of liquid nutrients uptake by plants. However, we could not rule out the possibility the higher antioxidant enzyme contents (SOD, CAT) in HP samples may be related to the stress factor.

On a related note, one parameter worth further investigation in the future study is how the differences in metal contents would affect the antioxidative potentials. Previously, leaves and fruits from hydroponic planted strawberries have been reported with higher mineral metal contents [14]. In our study using Indian borage as a medicinal plant model, we also observed a similar trend, whereby HP leaf extracts possessed higher metal contents, especially iron and magnesium (Figure 1). Previous studies also highlighted the importance of antioxidant minerals [47] and how 
metal level correlated with the antioxidant enzyme activity [48]. However, in our case, higher metal contents and higher antioxidative enzyme contents in HP samples did not correlate with the detected weaker DPPH and ABTS radical scavenging potentials (as indicated by their larger $\mathrm{EC}_{50}$ values). One possible explanation is that the antioxidant potentials contributed by higher mineral and antioxidant enzymes contents (Figure 1 and Table 4), may be counterbalanced by the lower phytochemical contents (Table 2) observed in our HP samples [36, 38]. This may help to explain why soilplanted Indian borage in this study, along with its higher phytochemical contents (in the range of 2.3-5.9 folds), was detected with stronger antioxidative potentials (as indicated by their smaller EC $_{50}$ values) (Table 1).

\section{Conclusion}

Using Plectranthus amboinicus (Indian borage) as a plant model showed that the use of different planting systems (soil versus hydroponics) could potentially affect the harvested plant's phytochemical, mineral, chlorophyll, carotenoid and antioxidant enzyme contents. In the future study, more plant models can be included in the comparison between HP and SP effects, to determine if similar phenomenon is observed. Through this study, it is hoped that more related information could be gathered and help to guide the choosing of the suitable planting systems with regard to food security, in terms of both harvest yields and nutritional contents.

\section{Acknowledgement}

We would like to extend our gratitude to funding support from UTAR Research Fund (UTARRF: Vote Number 6200/W80).

\section{References}

1. Swamy MK, Arumugam G, Kaur R et al. (2017) GC-MS Based Metabolite Profiling, Antioxidant and Antimicrobial Properties of Different Solvent Extracts of Malaysian Plectranthus amboinicus Leaves. Evid Based Complement Alternat Med 17: 1-10. doi: $10.1155 / 2017 / 1517683$

2. Choudhari AS, et al. (2020) Phytochemicals in Cancer Treatment: From Preclinical Studies to Clinical Practice. Frontiers in Pharmacology, 10, 1-18. doi: 10.3389/fphar.2019.01614.

3. Wong FC, Yong AL, Ting EP et al. (2014) Antioxidant, Metal Chelating, Anti-glucosidase Activities and Phytochemical Analysis of Selected Tropical Medicinal Plants. Iran J Pharm Res 13(4): 1409-1415. doi: 10.22037/IJPR.2014.1588.
4. Wadikar D, Patki P (2016) Coleus aromaticus: a therapeutic herb with multiple potentials. Journal of Food Science and Technology 53: 1-5. doi: 10.1007/s13197016-2292-y.

5. El-hawary SS, El-sofany RH, Abdel-Monem AR et al. (2012) Polyphenolics content and biological activity of Plectranthus amboinicus (Lour.) spreng growing in Egypt (Lamiaceae). Pharmacognosy Journal 4(32): 4554. doi: 10.5530/pj.2012.32.9.

6. Chiu YJ, Huang TH, Chiu CS et al. (2012) Analgesic and Antiinflammatory Activities of the Aqueous Extract from Plectranthus amboinicus (Lour.) Spreng. Both In Vitro and In Vivo. Evidence-based complementary and alternative medicine : eCAM 12: 50813-7. doi: 10.1155/2012/508137.

7. Patel R, Mahobia NK, Gendle R et al. (2010) Diuretic activity of leaves of Plectranthus amboinicus (Lour) Spreng in male albino rats. Pharmacognosy Res 2(2): 8688. doi: 10.4103/0974-8490.62956.

8. Viswanathaswamy AHM, Koti BC, Gore A et al. (2011) Antihyperglycemic and anti-hyperlipidemic activity of Plectranthus amboinicus on normal and alloxan-induced diabetic rats. Indian Journal of Pharmaceutical Sc 73(2): 139-145. doi: 10.4103/0250-474x.91572.

9. Sharma N, Acharya S, Kumar K et al. (2019) Hydroponics as an advanced technique for vegetable production: An overview. Journal of Soil and Water Conservation 17: 364-371. doi:10.5958/24557145.2018.00056.5.

10. Khan FA et al. (2018) A review on hydroponic greenhouse cultivation for sustainable agriculture. International Journal of Agriculture, Environment and Food Science, 2(2), 59-66. doi: 10.31015/jaefs.18010.

11. Ben-Hamadou R (2019) Hydroponics: Innovative Option for Growing Crops in Extreme Environments-The Case of the Arabian Peninsula (A Review). Open Access Journal of Agricultural Research 4: 1-4. doi:10.23880/OAJAR-16000235.

12. Treftz C, Omaye ST (2016) Hydroponics: potential for augmenting sustainable food production in non-arable regions. Nutrition and Food Science 46(5): 672-684. doi: 10.1108/NFS-10-2015-0118.

13. Sankhalkar S, Komarpant R, Dessai TR et al. (2019) Effects of Soil and Soil-Less Culture on Morphology, Physiology and Biochemical Studies of Vegetable Plants. Curr Agri Res 7(2): 181-188. doi: 10.12944/CARJ.7.2.06.

14. Jeon SH, Yoon YE, Lee YB et al. (2019) Are There as Many Essential and Non-essential Minerals in Hydroponic Strawberry (Fragaria ananassa L.) Compared to Those Grown in Soil? Biological Trace Element Research 187(2): 562-567. doi: 10.1007/s12011018-1394-y.

15. Manzocco L, Foschia M, Maifreni M et al. (2011) Influence of hydroponic and soil cultivation on quality and shelf life of ready-to-eat lamb's lettuce (Valerianella locusta L. Laterr). Journal of the Science of Food and Agriculture 91(8): 1373-1380. doi: 10.1002/jsfa.4313.

16. Wong FC, Chai TT, Hoo YW (2012) Antioxidation and cytotoxic activities of selected medicinal herbs used in Malaysia. Journal of Medicinal Plants Research 6(16): 3169-3175. doi: 10.5897/JMPR11.1631.

17. Malar S, Sahi SV, Favas PJ, Venkatachalam P (2015) Mercury heavy-metal-induced physiochemical changes and genotoxic alterations in water hyacinths [Eichhornia 
crassipes (Mart.)]. Environ Sci Pollut Res Int 22(6): 4597-4608. doi: 10.1007/s11356-014-3576-2.

18. Beauchamp C, Fridovich I (1971) Superoxide dismutase: Improved assays and an assay applicable to acrylamide gels. Analytical Biochemistry 44(1): 276-287. doi: 10.1016/0003-2697(71)90370-8.

19. Dhindsa RS, Plumb-Dhindsa P, Thorpe TA (1981) Leaf Senescence: Correlated with Increased Levels of Membrane Permeability and Lipid Peroxidation, and Decreased Levels of Superoxide Dismutase and Catalase. Journal of Experimental Botany 32(126): 93-101. doi: 10.1093/jxb/32.1.93.

20. Opie EL (1962) On the relation of necrosis and inflammation to denaturation of proteins. The Journal of experimental medicine 115(3): 597-608. doi: 10.1084/jem.115.3.597.

21. Mohana Dass S, Chai TT, Wong FC (2019) Antioxidant and Protein Protection Potentials of Fennel Seed-derived Protein Hydrolysates and Peptides. Modern Food Sc \& Tech 35(9): 22-29. doi: 10.13982/j.mfst.16739078.2019.9.002.

22. Chai TT, Xiao J, Mohana Dass S et al. (2021) Identification of antioxidant peptides derived from tropical jackfruit seed and investigation of the stability profiles. Food Chemistry 340: 127876. doi: 10.1016/j.foodchem.2020.127876.

23. Lichtenthaler HK (2001) Chlorophylls and Carotenoids: Measurement and Characterization by UV-VIS Spectroscopy. Current Protocols in Food Analytical $\begin{array}{llll}\text { Chemistry } & 4(3): & 1-8 .\end{array}$ 10.1002/0471142913.faf0403s01.

24. Dinesh B, Yadav B, Reddy RD et al. (2015) Determination of Ascorbic Acid Content in Some Indian Spices. Int. .J. Curr. Microbiol. App. Sci. 4(8): 864-868.

25. Uddin AB, Khalid RS, Alaama $M$ et al. (2016) Comparative study of three digestion methods for elemental analysis in traditional medicine products using atomic absorption spectrometry. Journal of Analytical Science and Technology 7(1): 6. doi: 10.1186/s40543016-0085-6.

26. Khan M, et al. (2021) Lead (Pb)-Induced Oxidative Stress Alters the Morphological and Physio-Biochemical Properties of Rice (Oryza sativa L.). Agronomy, 11(3), 116. doi: 10.3390/agronomy11030409.

27. Güneş A, Kordali Ş, Turan M, Usanmaz Bozhüyük A (2019) Determination of antioxidant enzyme activity and phenolic contents of some species of the Asteraceae family from medicanal plants. Industrial Crops \& Products 137: 208-213. doi: 10.1016/j.indcrop.2019.05.042.

28. Emamverdian A, Ding Y, Mokhberdoran, F, Xie, Y (2015) Heavy Metal Stress and Some Mechanisms of Plant Defence Response. Scientific World Journal, 2015, 1-19. doi: 10.1155/2015/756120.

29. Chai TT, Khoo CS, Tee CS, Wong FC (2016) Alphaglucosidase Inhibitory and Antioxidant Potential of Antidiabetic Herb Alternanthera sessilis: Comparative Analyses of Leaf and Callus Solvent Fractions. Pharmacognosy Magazine 12(48): 253-258. doi: 10.4103/0973-1296.192202.

30. Wong FC, Chai TT, Xiao J (2019) The influences of thermal processing on phytochemicals and possible routes to the discovery of new phytochemical conjugates.
Critical Reviews in Food Science and Nutrition 59(6): 947-952. doi: 10.1080/10408398.2018.1479681.

31. Wang J, Hu S, Nie S et al. (2016) Reviews on Mechanisms of In Vitro Antioxidant Activity of Polysaccharides. Oxidative Medicine and Cellular Longevity 16: 5692852. doi: 10.1155/2016/5692852.

32. Han RM, Zhang JP, Skibsted LH (2012) Reaction dynamics of flavonoids and carotenoids as antioxidants. Molecules 17(2): 2140-2160. doi: 10.3390/molecules17022140.

33. Hamlaoui I, Bencheraiet R, Bensegueni R, Bencharif M (2018) Experimental and theoretical study on DPPH radical scavenging mechanism of some chalcone quinoline derivatives. Journal of Molecular Structure 1156: 385-389. doi: 10.1016/j.molstruc.2017.11.118.

34. Helena A, Blaž G, Nataša Poklar U, Blaž C (2018) Relevance and Standardization of In Vitro Antioxidant Assays: ABTS, DPPH, and Folin-Ciocalteu. Journal of Chemistry 2018. doi: 10.1155/2018/4608405.

35. Shahidi F, Zhong Y (2015) Measurement of antioxidant activity. Journal of Functional Foods 18: 757-781. doi: 10.1016/j.jff.2015.01.047.

36. Cao H, Chai TT, Wang X et al. (2017) Phytochemicals from fern species: potential for medicine applications. Phytochemistry Reviews 16(3): 379-440. doi: 10.1007/s11101-016-9488-7.

37. Chai TT, Panirchellvum E, Ong HC, Wong FC (2012) Phenolic contents and antioxidant properties of Stenochlaena palustris, an edible medicinal fern. Botanical Studies 53(4): 439-446.

38. Chai TT, Ooh KF, Quah Y, Wong FC (2015) Edible freshwater macrophytes: a source of anticancer and antioxidative natural products-a mini-review. Phytochemistry Reviews 14(3): 443-457. doi: 10.1007/s11101-015-9399-z.

39. Chai TT, Xiao JB, Mohana Dass S, Wong FC (2020) Laccase-catalyzed, Phytochemical-mediated Protein Cross-linking Conjugates. eFood 1(2): 119-125. doi: 10.2991/efood.k.200218.001.

40. Pérez-Gálvez, A., Viera, I. \& Roca, M., 2020. Carotenoids and Chlorophylls as Antioxidants. Antioxidants, 9 (6): 1-34. doi: 10.3390/antiox9060505.

41. Li L, Yi H (2012) Effect of sulfur dioxide on ROS production, gene expression and antioxidant enzyme activity in Arabidopsis plants. Plant Physiology and Biochem 58: 46-53. doi: 10.1016/j.plaphy.2012.06.009.

42. Kapoor D, Singh S, Kumar V et al. (2019) Antioxidant enzymes regulation in plants in reference to reactive oxygen species (ROS) and reactive nitrogen species (RNS). Plant Gene 19: 100182. doi: 10.1016/j.plgene.2019.100182.

43. Kabiri R, Farahbakhsh H, Nasibi F (2012) Salicylic Acid Ameliorates the Effects of Oxidative Stress Induced by Water Deficit in Hydroponic Culture of Nigella sativa. Journal of Stress Physiology \& Biochem 8(3): 13-22.

44. Li ZW, Yang Y, Cui XM, Liao PR, Ge J, Wang CX, Yang XY, Liu DH (2015) Physiological response and bioaccumulation of Panax notoginseng to cadmium under hydroponic. China journal of Chinese materia medica 40(15): 2903-2908. doi: 10.4268/cjcmm20151501.

45. Shekari L, Kamelmanesh MM, Mozafariyan M et al. (2017) Role of selenium in mitigation of cadmium toxicity in pepper grown in hydroponic condition. Journal 
of Plant Nutrition 40(6): 761-772. doi: 10.1080/01904167.2016.1161773.

46. Armas T, Pinto A, Varennes A et al. (2015) Comparison of cadmium-induced oxidative stress in Brassica juncea in soil and hydroponic cultures. Plant \& Soil 388(1/2): 297-305. doi: 10.1007/s11104-014-2330-3.

47. Muhammad SA, Bilbis LS, Saidu Y, Adamu Y (2012) Effect of Antioxidant Mineral Elements Supplementation in the Treatment of Hypertension in Albino Rats. Oxidative Medicine and Cellular Longevity 2012: 134723. doi: 10.1155/2012/134723.

48. Boriskin P et al. (2020) Correlation of the distribution of antioxidant enzyme concentrations in blood serum and heart tissue in rats. BIO Web of Conferences, 17(1), 1-6. doi: 10.1051/bioconf/20201700234. 
This page is intentionally left blank. 